\title{
고온고습환경이 $\mathrm{Sn}$ 계 무연솔더의 부식 및 기계적 특성에 미치는 영향
}

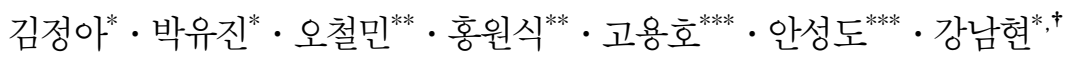 \\ *부산대학교 재료공학과 \\ **전자부품연구원 시스템로버스트 연구센터 \\ ***한국생산기술연구원 마이크로조이닝센터
}

\section{Effects of High Temperature-moisture on Corrosion and Mechanical Properties for Sn-system Solder Joints}

\author{
Jeonga Kim*, Yujin Park*, Chul Min Oh**, Won Sik Hong**, Yong-Ho Ko***, \\ Sungdo Ahn***, and Namhyun Kang*, $\uparrow$ \\ *Department of Materials Science and Engineering, Pusan National University, Busan 46241, Korea \\ **Components and Materials Physics Research Center, Korea Electronic Technology Institute, \\ Seongnam 13515, Korea \\ ***Microjoining Center, Korea Institute of Industrial Technology, Incheon 21999, Korea
}

†Corresponding author : nhkang@pusan.ac.kr

(Received June 7, 2017 ; Revised June 14, 2017 ; Accepted June 28, 2017)

\begin{abstract}
The effect of high temperature-moisture on corrosion and mechanical properties for $\mathrm{Sn}-0.7 \mathrm{Cu}, \mathrm{Sn}-3.0 \mathrm{Ag}-0.5 \mathrm{Cu}$ (SAC305) solders on flexible substrate was studied using Highly Accelerated Temperature/Humidity Stress Test (HAST) followed by three-point bending test. Both $\mathrm{Sn}-0.7 \mathrm{Cu}$ and $\mathrm{SAC} 305$ solders produced the internal $\mathrm{SnO}_{2}$ oxides. Corrosion occurred between the solder and water film near flexible circuit board/copper component. For the SAC305 solder with Ag content, furthermore, octahedral corrosion products were formed near Ag3Sn. For the SAC305 and Sn-0.7Cu solders, the amount of internal oxide increased with the HAST time and the amount of internal oxides was mostly constant regardless of Ag content. The size of the internal oxide was larger for the $\mathrm{Sn}-0.7 \mathrm{Cu}$ solder. Despite of different size of the internal oxide, the fracture time during threepoint bending test was not significantly changed. It was because the bending crack was always initiated from the three-point corner of the chip. However, the crack propagation depended on the oxides between the flexible circuit board and the $\mathrm{Cu}$ chip. The fracture time of the three-point bending test was dependent more on the crack initiation than on the crack propagation
\end{abstract}

Key Words : Lead-free, Solder joint, Corrosion, Three-point bending, Flexible circuit board

\section{1. 서 론}

오늘날 친환경 소재사용에 대한 환경규제 법안에 의해 전자제품에서의 무연솔더 적용은 이미 상용화 되었다 ${ }^{1)}$. 자동차 전장부품도 2016년부터 유해물질규제(RoHS)가 발 효되었고, 유럽의 폐차처리지침(End-of-Life Vehicle, $\mathrm{ELV}$ )에서는 자동차에 사용되는 4대 중금속(납, 수은,
카드뮴, 6 가 크롬)을 포함하는 부품의 사용 금지를 결 정하였다 ${ }^{2-4)}$. 이와 같은 이유로 자동차 전장부품에는 납이 함유되지 않은 무연부품과 무연솔더를 적용하여야 한다.

$\mathrm{Sn}$ 계 무연솔더는 일반적인 작동환경에서 산화를 방 지하는 $\mathrm{Sn}$ 산화층이 표면에 형성되어 높은 내식성을 가 진다고 알려져 있다. 그러나 솔더가 고온고습, halide 이온과 같은 가혹한 환경에 노출되면 부식이 일어나게 
된다 ${ }^{5,6)}$. 이에 따른 부식생성물에 의해 솔더 접합부는 전기적 단락을 야기하고 기계적 특성이 감소한다 ${ }^{7-10)}$. 솔더 표면에 부식이 일어나는 경우, 부식생성물은 크랙 이 시작되는 주요 요인이 되지만, 가혹한 환경에서의 산화 메커니즘과 기계적 특성에 대한 연구는 아직 미흡 한 단계이다.

일반적인 전자제품과 달리 고온, 고습, 열 충격, 진동, 오염 등의 가혹한 환경에 노출되어있는 자동차 전장부 품의 경우 신뢰성을 보증하기 위한 연구가 필요하다. 일반적인 전자제품은 $-30^{\circ} \mathrm{C}$ 에서 $+85^{\circ} \mathrm{C}$ 의 온도범위를 2-5년 수명을 요구하지만, 자동차 전장부품은 $-40^{\circ} \mathrm{C}$ 에 서 $+125^{\circ} \mathrm{C}$ 의 온도범위에서 5-10년의 수명을 요구한 다. 그리고 자동차 전장부품의 솔더 접합부가 실외에서 받는 스트레스 인자인 열, 습기, 진동 등에 의해 지속 적 피로스트레스가 가해지면 솔더 접합부에 열화가 진 행된다 ${ }^{11-13)}$. 따라서 본 연구는 고온고습시험(Highly Accelerated Temperature/Humidity Stress Test; $\mathrm{HAST}$ )에서 시험시간에 따라 에어백 충격센서 일체형 차체부품 접합에 적용된 $\mathrm{Sn}-3.0 \mathrm{Ag}-0.5 \mathrm{Cu}$ (SAC305), $\mathrm{Sn}-0.7 \mathrm{Cu}$ 무연솔더 접합부의 부식 및 굽힘 특성을 연 구하였다.

\section{2. 실험방법}

\section{1 시편 제작}

연성기판에 에어백 센서칩을 무연솔더로 실장했을 때 의 고온고습 및 굽힘 특성을 분석하기 위해 시편은 Fig. 1 과 같이 제작하였다. Small Outline Integrated Circuit (SOIC) 칩과 연성회로기판 사이의 접합을 위해 사용된 솔더는 $\mathrm{Ag}$ 함량에 따라 $\mathrm{Sn}-0.7 \mathrm{Cu}$ 와 $\mathrm{SAC} 305$ 를 사용 하였다. $\mathrm{Sn}-0.7 \mathrm{Cu}$ 솔더의 리플로우 공정 조건은 최고 온도 $256^{\circ} \mathrm{C}$, 예열시간 90 초, 용융지속시간 50 초, 총

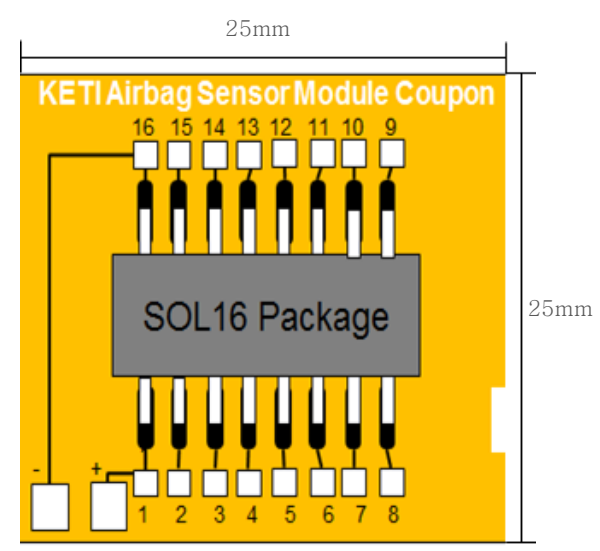

Fig. 1 SOIC16-package design mounted on flexible substrate

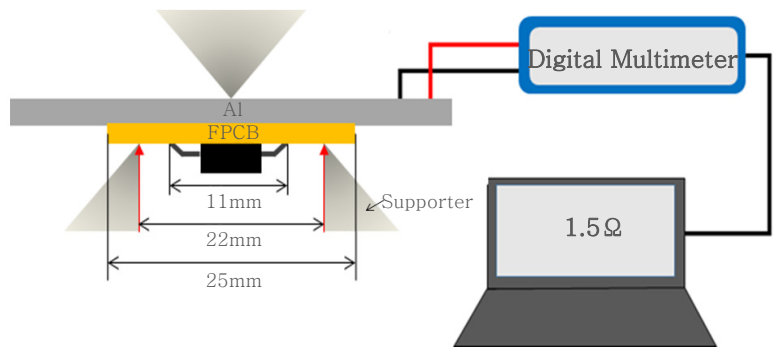

Fig. 2 Schematic diagram of 3-point bending test

리플로우 시간 약 5 분이고, SAC305 솔더는 최고 온도 만 $245^{\circ} \mathrm{C}$ 로 다른 조건을 사용하였다.

\section{2 고온 고습 및 굽힘 시험}

차체와 센서모듈 간 접합부에 대한 환경내구신뢰성을 평가하기 위해 HAST 실험을 진행하였다. 시험조건은 $121^{\circ} \mathrm{C}, 100 \% \mathrm{RH}$ (Relative Humidity), $2 \mathrm{~atm}$ 의 고온 고습환경에서 각각 $0,48,72,96$ 시간 동안 시편을 노 출시켰다. HAST 시험을 마친 연성회로기판 시편 뒤에 $1 \mathrm{~mm}$ 두께의 얇은 알루미늄 판을 탄성에폭시접착체로 접착하여 굽힘 시험이 가능하도록 하였다.

Fig. 2는 3점 굽힘시험의 모식도이다. Supporters 사이의 간격을 $22 \mathrm{~mm}$ 로 유지하고 Supporter에 알루 미늄 판을 붙인 시편을 고정시킨 후 $1 \mathrm{~mm} / \mathrm{min}$ 의 굽힘 속도로 시편의 중앙 지점에 일정 하중을 가하였다. 칩 접합부의 파단 유무를 알기 위해 Fig. 2 와 같이 연성회 로기판과 $\mathrm{SOIC}$ 칩 사이에 전기적 도통 실험을 하였다. 크랙여부 판단은 디지털 멀티메타를 이용해서 초단위로 실시간 저항을 측정하였으며, 파단의 판단은 저항이 급 격히 증가하여 무한대가 되는 시점으로 정하였다.

\section{3 미세조직 분석}

접합부의 단면분석을 위해 콜드마운팅한 시편은 2400 까지 연마하였고, 그 후 $3 \mu \mathrm{m}$ 부터 $0.05 \mu \mathrm{m}$ 의 $\mathrm{Al}_{2} \mathrm{O}_{3}$ 파우 더로 기계적 폴리싱을 하였다. 폴리싱된 시편은 에칭 없 이 미세조직 관찰을 위해 후방산란전자를 이용한 Scanning electron microscopy (SEM)와 조성분석을 위 해 Energy dispersive spectroscopy (EDS)를 수행 하였다. 솔더 내 분포한 석출물 및 산화물형태와 조성 분석을 위해 Electron probe X-ray microanalysis (EPMA)를 사용하였다.

산화물의 크기는 산화물의 중점을 지나는 지름선을 $2^{\circ}$ 간격으로 모두 측정한 값들의 평균값을 사용하였다. 산화물의 분율은 저배율로 관찰된 솔더 접합부 전체의 면적 대비 산화물이 차지하는 면적의 비율로 정의하였 
다. 접합부의 표면에서 관찰되는 산화막은 산화물의 크 기와 분율 계산에 포함되지 않았다. 관찰되는 측정값의 신뢰도를 높이기 위해 같은 조건에서 제작된 2-3개의 다른 시편 단면을 관찰하였다.

\section{3. 결과 및 고찰}

\section{1 $\mathrm{Ag}$ 함량에 따른 부식 거동}

Fig. 3은 HAST 전후의 SAC305 솔더 단면이다. $\mathrm{HAST}$ 시험 전에는 주로 표면 부근에서 산화물이 발견 되었고, 연성기판의 $\mathrm{Cu}$ 패드와 $\mathrm{SOIC} 16$ 칩의 $\mathrm{Cu}$ 리 드와의 접합부에서는 $\mathrm{Sn}$ 계 산화물이 거의 발견되지 않 았다. (Figs. 3a, 3b) HAST 시간이 48h로 진행되면 서 산화물 생성은 $\mathrm{Cu}$ 리드 부근에서 먼저 생성되었으 며 (Fig. $3 \mathrm{c}$ ), HAST가 $72 \mathrm{~h}$ 로 증가할수록 $\mathrm{Cu}$ 리드 부근과 연성기판의 $\mathrm{Cu}$ 패드와 솔더 사이까지 산화물이 생성되었다. Fig. 3d) HAST 시험 시간이 증가하면서 내부 산화물의 분율은 증가하였다.

Fig. 4는 $\mathrm{Ag}$ 가 함유되지 않은 $\mathrm{Sn}-0.7 \mathrm{Cu}$ 솔더의 HAST 전후 단면 사진이다. Fig. $4 \mathrm{a}$ 에서 HAST 전에는 표면 에만 산화물이 생성되는 것을 알 수 있고, HAST 시험 시간이 48h, $72 \mathrm{~h}$ 로 증가할수록 $\mathrm{Cu}$ 리드와 연성회로기 판 사이에 조대한 산화물이 발견되었다. (Figs. 4c, 4d) $\mathrm{SAC} 305$ 솔더와 동일하게 $\mathrm{Sn}-0.7 \mathrm{Cu}$ 솔더 접합부도 $\mathrm{Sn}$ 산화물이 발견되었으며, 시험 시간이 증가할수록 내부 산화물의 양이 증가하였다.

Fig. 5는 HAST 시험 시간 48h에서의 SAC305와 $\mathrm{Sn}^{-}$ $0.7 \mathrm{Cu}$ 산화물을 도시하였다. $\mathrm{Ag}$ 가 함유된 $\mathrm{SAC} 305$ 솔더는 Fig. $5 \mathrm{a}$ 처럼 $\mathrm{Sn}$ 계 산화물 내부에 $\mathrm{Ag}_{3} \mathrm{Sn}$ 금속
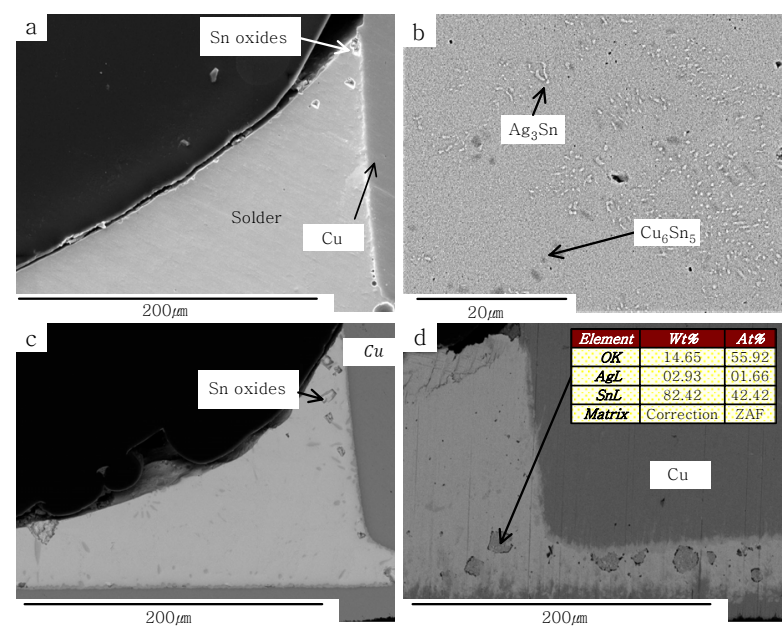

Fig. 3 Cross-sections of SAC305 solder joints after exposure at $121^{\circ} \mathrm{C}, 2 \mathrm{~atm}, 100 \% \mathrm{RH}$ during $(\mathrm{a}, \mathrm{b}) 0 \mathrm{~h}$, (c) $48 \mathrm{~h}$, and (d) $72 \mathrm{~h}$
간 화합물이 발견되었다. Fig. 5b는 SAC305 솔더 내 부의 $\mathrm{Sn}$ 계 산화물이 연마 중 빠져나간 자국이다. $\mathrm{Ag}$ 가 함유되지 않은 $\mathrm{Sn}-0.7 \mathrm{Cu}$ 솔더는 산화물 내부에 금속 간화합물이 확인되지 않았다. $\mathrm{Ag}$ 가 함유된 $\mathrm{SAC} 305$ 솔더 내부의 산화물은 대부분 Octahedral형태의 다각형 모양이고 ${ }^{14)}$, 같은 시간 동안 $\mathrm{HAST}$ 진행시 $\mathrm{Sn}-0.7 \mathrm{Cu}$ 솔더 내부의 산화물 표면은 대부분 노출된 면이 많은 다각형 형태를 띤다. $\mathrm{Ag}$ 가 함유되지 않은 $\mathrm{Sn}-0.7 \mathrm{Cu}$ 솔더 접합부의 산화물은 Fig. 4에서와 같이 대부분 표 면과 $\mathrm{Cu}$ 패드/리드와 인접한 부분에 산화물이 분포하 였고, 이는 고온고습환경에서 솔더가 표면에 형성된 수 분막과 전기화학적 결합하여 상대적으로 부식전위가 높 은 $\mathrm{Cu}$ 주변부에서 산화 반응이 일어나 $\mathrm{Sn}$ 계 산화물이 발생한 것으로 판단된다. Lahokallio ${ }^{15)}$ 는 탈이온수에 담궈진 $50 \mu \mathrm{m}$ 두께의 Polyimide(PI)가 48시간이 지난 후 수분 흡수율이 $2 \%$ 가 넘어가는 것을 확인했다. 따라
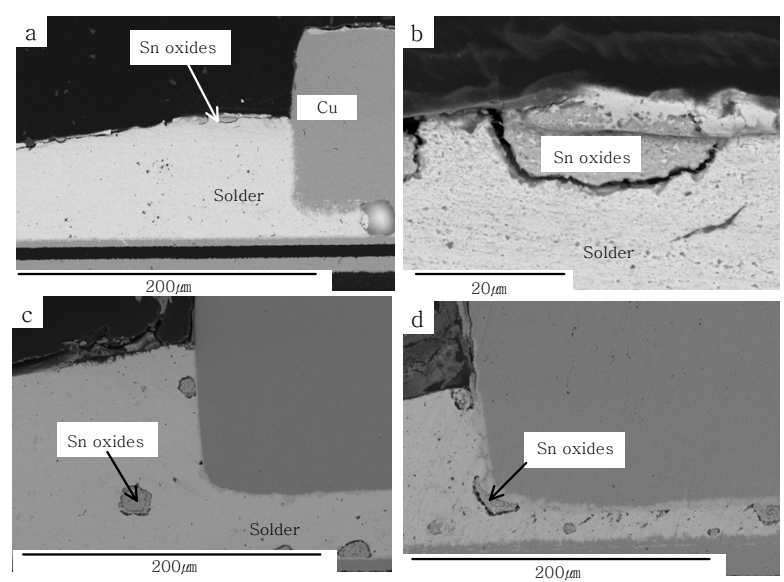

Fig. 4 Cross-sections of $\mathrm{Sn}-0.7 \mathrm{Cu}$ solder joints after exposure at $121^{\circ} \mathrm{C}, 2 \mathrm{~atm}, 100 \% \mathrm{RH}$ during $(\mathrm{a}, \mathrm{b}) 0 \mathrm{~h}$, (c) $48 \mathrm{~h}$, and (d) $72 \mathrm{~h}$
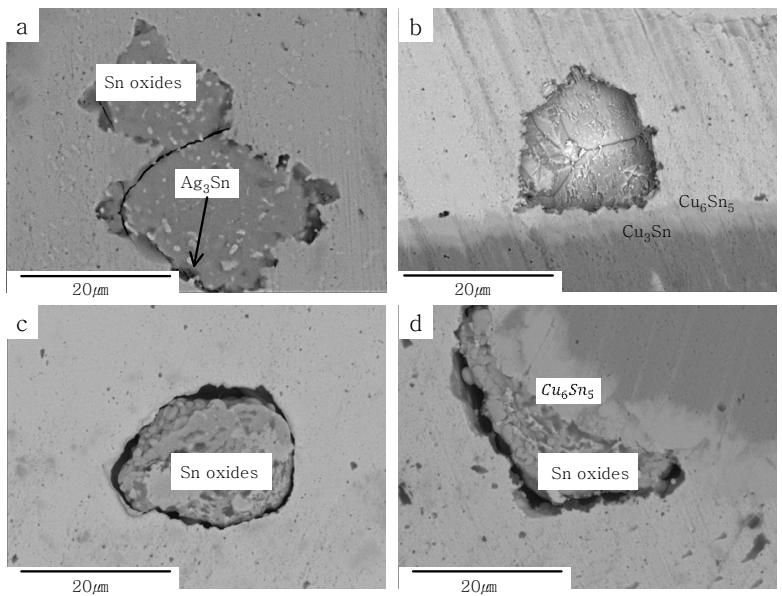

Fig. 5 Morphology of corrosion byproducts after exposure at $121{ }^{\circ} \mathrm{C}, 2 \mathrm{~atm}, 100 \% \mathrm{RH}$ during $48 \mathrm{~h}$ for(a,b) SAC305 and (c,d) Sn-0.7Cu 
서 고온고습 분위기에서 흡습성이 좋은 $\mathrm{PI}$ 기반의 연성 기판을 통해 흡수된 $\mathrm{H}_{2} \mathrm{O}$ 와 반응하여 수산화 이온을 생성하고(식1), 생성된 수산화이온이 솔더의 $\mathrm{Sn}$ 과 반 응하여 수산화주석이 된다. (식2-4) 수산화주석은 탈수 되면서 최종적으로 $\mathrm{Sn}$ 산화물이 생성된다. (식5-7) $\mathrm{Ag}$ 가 함유된 $\mathrm{SAC} 305$ 솔더는 추가적으로 $\mathrm{Ag}_{3} \mathrm{Sn}$ 에서도 산화물이 생성되는 것을 확인 할 수 있다. 이는 $\mathrm{Cu}$ 패 드/리드 주위 뿐만 아니라 솔더 내의 $\mathrm{Sn}$ 보다 부식전위 가 높은 $\mathrm{Ag}_{3} \mathrm{Sn}$ 주변부에서도 $\mathrm{Sn}$ 산화물이 생성됨을 의 미한다. (식8,9) Wang ${ }^{16,17)}$ 은 고온고습환경에서 SAC305 솔더가 $\mathrm{Ag}_{3} \mathrm{Sn}$ 금속간화합물에서 선택적 산화가 일어나 는 것을 확인하였다. Wang의 연구는 솔더 접합부 표면 에 형성된 산화막을 제거하고 관찰되는 산화물을 연구한 반면, 본 연구는 $\mathrm{Cu}$ 리드/부품과 솔더와의 계면을 중심 으로 접합부 단면에서 관찰된 내부 산화물의 형성에 대 한 내용이다. 즉 $\mathrm{SAC} 305$ 솔더에 존재하는 $\mathrm{Ag}_{3} \mathrm{Sn}$ 이 산화물 형성에 미치는 메커니즘은 산화물의 관찰 방법 은 다르더라도 동일하게 적용하였다.

$$
\begin{aligned}
& \mathrm{O}_{2}+4 e^{-}+2 \mathrm{H}_{2} \mathrm{O} \rightarrow 4 \mathrm{OH}^{-} \\
& \mathrm{Sn}+2 \mathrm{OH}^{-}-2 e^{-} \rightarrow \mathrm{Sn}(\mathrm{OH})_{2} \\
& \mathrm{Sn}(\mathrm{OH})_{2}+2 \mathrm{OH}^{-}-2 e^{-} \rightarrow \mathrm{Sn}(\mathrm{OH})_{4} \\
& \mathrm{SnO}+\mathrm{H}_{2} \mathrm{O}+2 \mathrm{OH}^{-}-2 e^{-} \rightarrow \mathrm{Sn}(\mathrm{OH})_{4} \\
& \mathrm{Sn}(\mathrm{OH})_{2} \rightarrow \mathrm{SnO}+\mathrm{H}_{2} \mathrm{O} \\
& \mathrm{Sn}(\mathrm{OH})_{4} \rightarrow \mathrm{SnO}_{2}+2 \mathrm{H}_{2} \mathrm{O} \\
& \mathrm{Sn}+\mathrm{O}_{2} \rightarrow \mathrm{SnO}_{2}
\end{aligned}
$$

Fig. 6은 산화물의 조성이 Sn계 산화물임을 알 수 있는 $\mathrm{EPMA}$ 결과이다. 산화물은 솔더와 $\mathrm{Cu}_{6} \mathrm{Sn}_{5}$ 금속 간화합물 사이에 위치하고 있었다. $\mathrm{SnO}_{2}, \mathrm{SnO}, \mathrm{CuO}$, $\mathrm{Ag}_{2} \mathrm{O}$ 각 조성의 산화물이 생성되기 위한 Gibbs free energy는 각각 $-515.8,-251.9,-129.7,-11.2(\mathrm{KJ} / \mathrm{mol})$ 이다. 즉, $\mathrm{SAC} 305$ 와 $\mathrm{Sn}-0.7 \mathrm{Cu}$ 조성의 솔더 내부에 는 $\mathrm{SnO}_{2}$ 또는 $\mathrm{SnO}$ 와 같은 $\mathrm{Sn}$ 계 산화물이 가장 생성 되기 쉽기 때문에, 두 솔더의 접합부에서 $\mathrm{HAST}$ 시험 후 관찰된 산화물은 $\mathrm{EDS}$ 결과와 마찬가지로 $\mathrm{Sn}$ 계 산 화물이다.

\section{$3.2 \mathrm{Ag}$ 함량에 따른 산화물 분율}

Fig. 7은 HAST 시간에 따라 $\mathrm{Ag}$ 가 $3 \mathrm{wt} . \%$ 함유된 $\mathrm{SAC} 305$ 솔더와 $\mathrm{Ag}$ 가 없는 $\mathrm{Sn}-0.7 \mathrm{Cu}$ 솔더의 내부

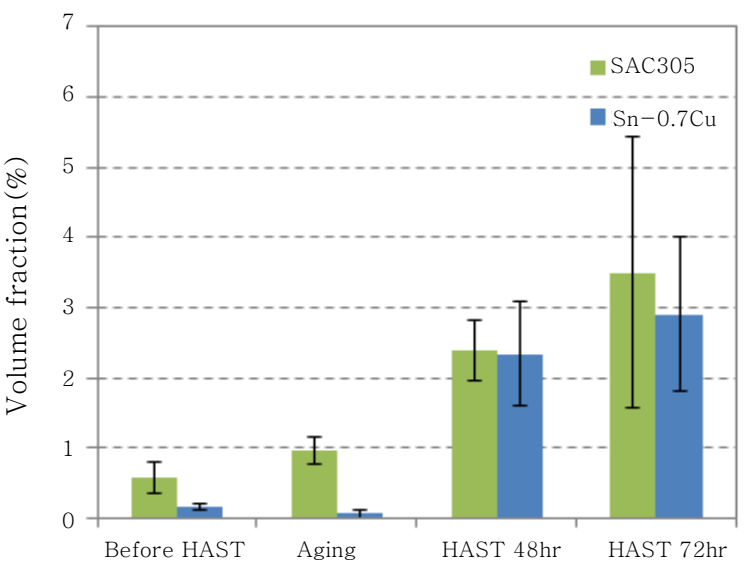

Fig. 7 Volume fraction of Sn oxides

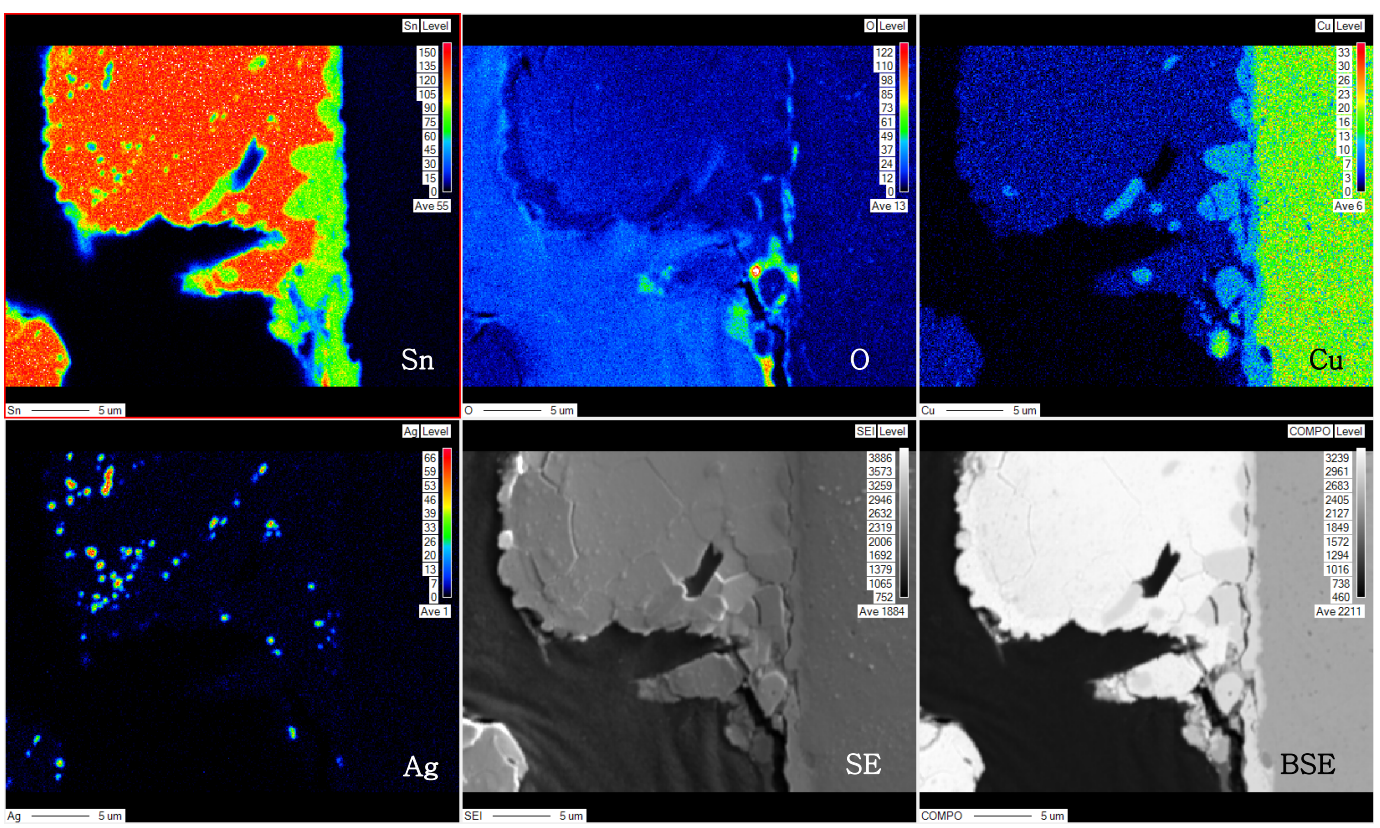

Fig. 6 EPMA image of SAC305 solders after exposure at $121^{\circ} \mathrm{C}$, 2atm, 100\% RH, and $48 \mathrm{~h}$ 
산화물 분율을 나타낸다. 습기가 없는 $\mathrm{Ar}$ 분위기에서도 내부 부식물 생성이 발생하는 지 확인하기 위해 $121^{\circ} \mathrm{C}$, $72 \mathrm{~h}$ thermal aging한 결과도 포함하였다. Thermal aging한 SAC305 접합부는 $\mathrm{Ag}_{3} \mathrm{Sn}$ 금속간 화합물 흔 적과 함께 내부 산화물이 발견되었고, $\mathrm{Sn}-0.7 \mathrm{Cu}$ 접합 부도 내부 산화물이 발견되었다. 그러나 내부 산화물의 분율은 $\mathrm{SAC} 305$ 와 $\mathrm{Sn}-0.7 \mathrm{Cu}$ 솔더 모두 $1 \mathrm{vol} \%$ 미 만으로 $\mathrm{HAST}$ 전과 비슷한 양을 보였다. 48시간 $\mathrm{HAST}$ 시험한 시편은 $\mathrm{SAC} 305$ 와 $\mathrm{Sn}-0.7 \mathrm{Cu}$ 접합부 에서 각각 $2.4 \mathrm{vol} . \%$ 와 $2.1 \mathrm{vol} \%$ 의 내부 산화물 분율 을 보였다. 그리고 72 시간 HAST 시험한 경우 내부 산화물 분율은 각각 $3.5 \mathrm{vol} \%$ 와 $2.9 \mathrm{vol} \%$ 였다. 두 솔 더 모두 $\mathrm{HAST}$ 시험 후 산화물 분율이 증가하였고, $\mathrm{HAST}$ 실시 후 48시간까지 산화물 분율은 증가하였지 만 그 이후는 큰 차이가 없었다. HAST 시험 이전에는 $\mathrm{Ag}$ 를 함유한 $\mathrm{SAC} 305$ 솔더 접합부가 더 많은 내부 산 화물을 가지고 있었지만, HAST 시간이 증가함에 따라 $\mathrm{Ag}$ 함량이 내부 산화물 분율에 주는 영향은 거의 없었 다. Thermal aging 실험결과를 통하여 $121^{\circ} \mathrm{C}$ 온도 이외에도 $2 \mathrm{~atm}, 100 \% \mathrm{RH}$ 분위기가 내부 산화물 생 성과 성장에 큰 영향을 주었음을 확인하였다.
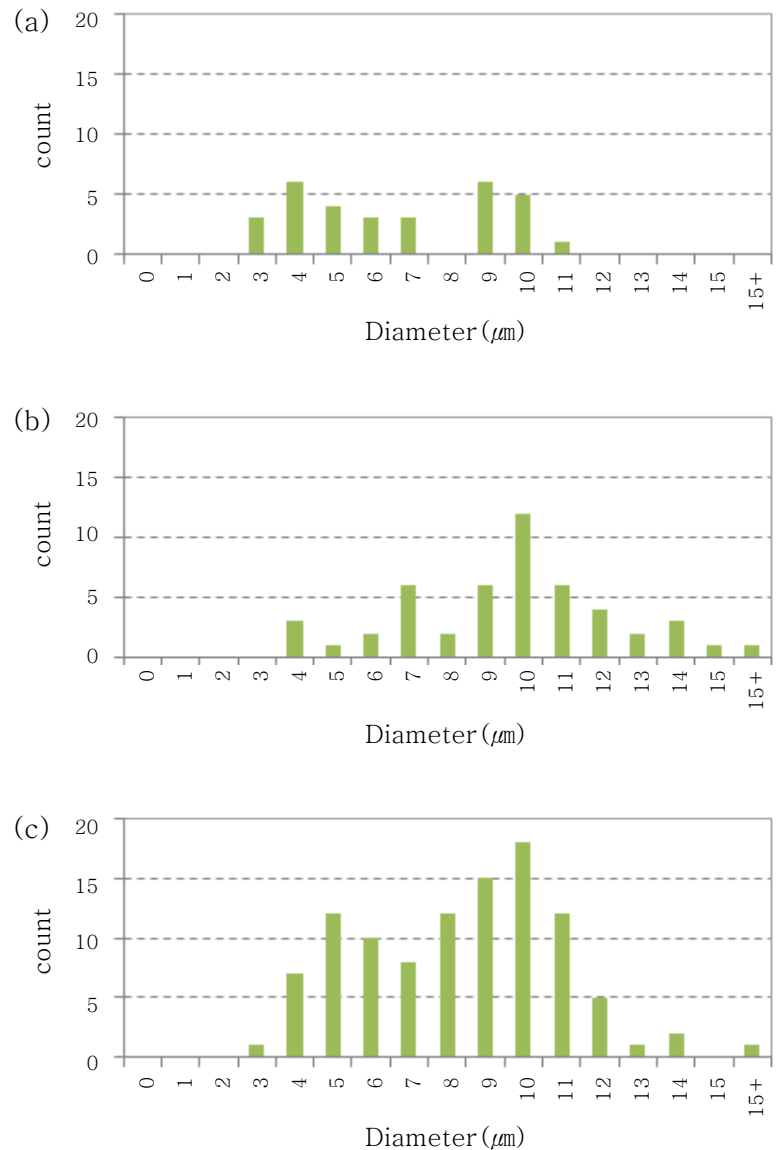

Fig. 8은 각 솔더의 내부 산화물 크기를 나타낸다. $\mathrm{HAST}$ 시험 전 SAC305 솔더의 산화물 지름은 $7.1 \mu \mathrm{m}$ 이였으며, $48 \mathrm{~h} \mathrm{HAST}$ 시험 후 $9.6 \mu \mathrm{m}$ 로 증가하였고, $72 \mathrm{~h} \mathrm{HAST}$ 시험까지는 $9.5 \mu \mathrm{m}$ 의 산화물 지름을 가지고 있었다. $\mathrm{Sn}-0.7 \mathrm{Cu}$ 솔더 접합부는 $\mathrm{HAST}$ 시험 전 지 름 $9.3 \mu \mathrm{m}$ 의 내부 산화물을 가지고 있었고, $48 \mathrm{~h}$ 와 $72 \mathrm{~h}$ $\mathrm{HAST}$ 시험에서는 각각 $11.4 \mu \mathrm{m}$ 와 $14.3 \mu \mathrm{m}$ 의 크기를 나 타내었다. SAC305솔더는 HAST 시험 후 산화물의 크 기가 증가하였으나, 48시간 이후 부터는 큰 차이가 없

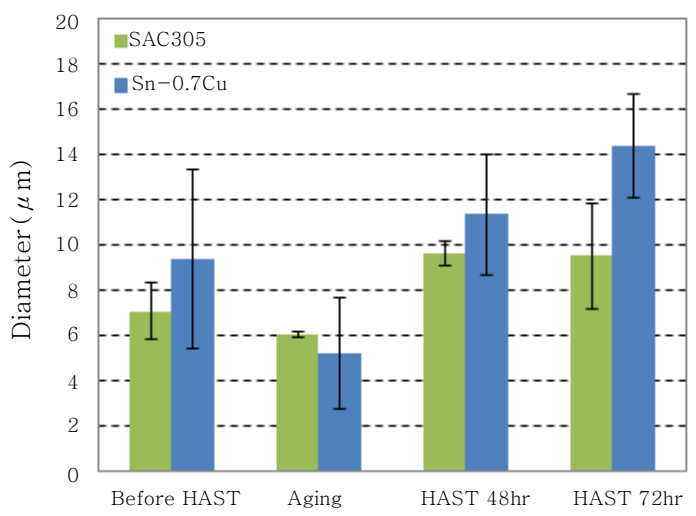

Fig. 8 Diameter of Sn oxides
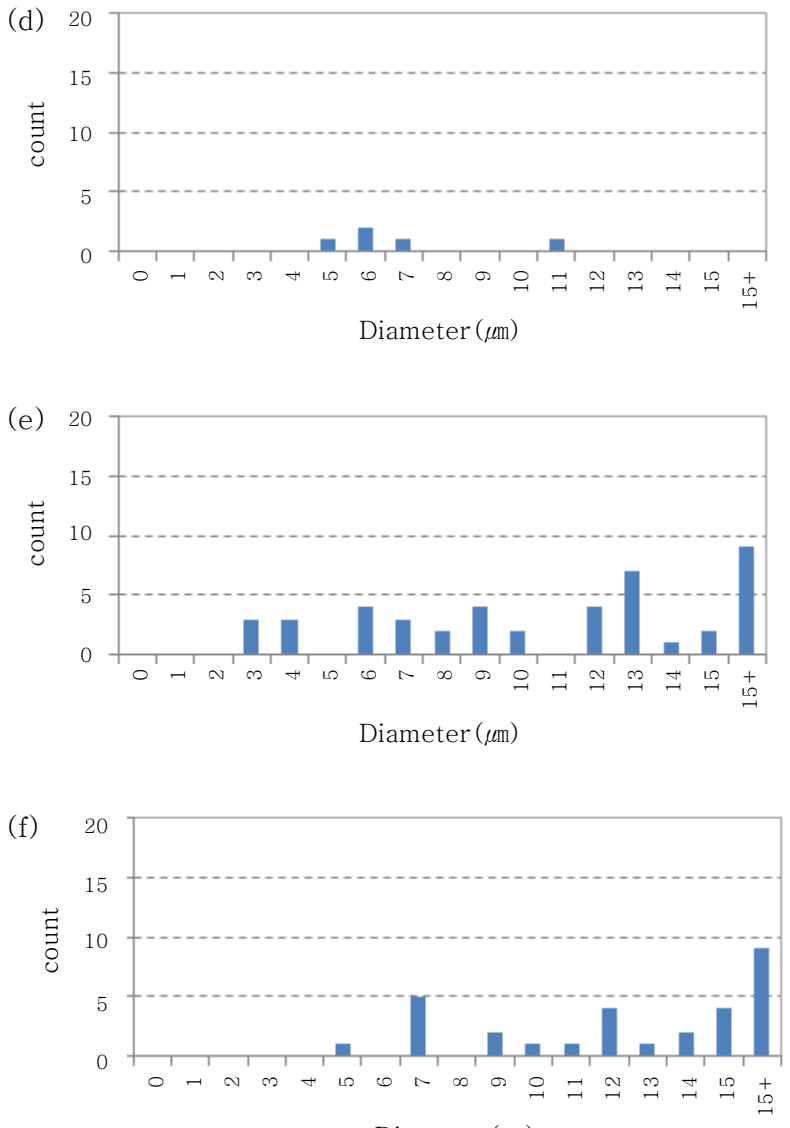

Diameter $(\mu \mathrm{m})$

Fig. 9 Histogram of Sn-oxide diameter tested at $121^{\circ} \mathrm{C}$, 2atm, and 100\% RH : (a,b,c) 0, 48, 72h respetively for SAC305 and (d,e,f) $0,48,72 \mathrm{~h}$ respectively for $\mathrm{Sn}-0.7 \mathrm{Cu}$ 
었다. $\mathrm{Sn}-0.7 \mathrm{Cu}$ 솔더는 $\mathrm{HAST}$ 시험 시간이 증가할수 록 내부 산화물의 크기가 증가 하는 것을 알 수 있다. HAST 시험 전 결과와 thermal aging한 솔더 접합부 에서의 내부 산화물 크기는 실험적 표준편차를 고려하 면 비슷한 값을 나타내었다. $\mathrm{Ag}$ 를 함유하지 않은 $\mathrm{Sn}^{-}$ $0.7 \mathrm{Cu}$ 솔더 접합부와 $\mathrm{Ag}$ 를 함유한 $\mathrm{SAC} 305$ 솔더 접 합부는 HAST 전과 $48 \mathrm{hr}$ 시간까지 거의 비슷한 내부 산화물의 크기를 가지고 있었지만, HAST $72 \mathrm{hr}$ 에서 는 SAC305 솔더 접합부가 더 작은 크기의 내부 산화 물을 가지고 있었다. Figs. 7과 8을 통해 $\mathrm{Ag}$ 가 함유된 $\mathrm{SAC} 305$ 솔더 보다 $\mathrm{Ag}$ 가 없는 $\mathrm{Sn}-0.7 \mathrm{Cu}$ 솔더가 HAST 시간이 증가할수록 산화물의 양은 큰 차이가 없고 산화 물의 크기는 크게 증가한 것을 확인하였다.

Fig. 9는 각 솔더의 $\mathrm{Sn}$ 계 산화물 크기 분포의 히스토 그램을 나타낸다. $\mathrm{Ag}$ 가 함유된 $\mathrm{SAC} 305$ 솔더는 HAST 시간이 증가 할수록 내부 산화물의 크기는 증가하지만 평균값과 유사한 크기의 산화물이 증가하여 전체적인 분율이 증가하는 것을 알 수 있다. $\mathrm{Ag}$ 가 함유되지 않은 $\mathrm{Sn}-0.7 \mathrm{Cu}$ 솔더는 $\mathrm{HAST}$ 시간이 증가할수록 $15 \mu \mathrm{m}$ 가 넘는 조대한 크기의 산화물이 발견되어 전체적인 분율 이 증가하였다. $\mathrm{Sn}-0.7 \mathrm{Cu}$ 솔더의 $\mathrm{HAST}$ 이후 시편에 서 산화물 크기의 편차가 큰 이유는 SAC305 솔더보다 조대한 크기의 산화물이 형성되었기 때문으로 판단된다 (Fig. 8).

Fig. 10은 솔더에서의 $\mathrm{Ag}$ 함량에 따른 $\mathrm{Sn}$ 계 산화물 생성의 메커니즘을 도식화 하였다. Figs. 3-5에서 Ag 가 함유되지 않은 솔더 접합부에서 산화물 핵생성의 위 치는 $\mathrm{Sn}$ 보다 부식 전위가 높은 $\mathrm{Cu}$ 패드/리드 주변부 에서 산화 반응이 일어난 것이다. 반면 $\mathrm{Ag}$ 가 함유된 솔 더의 접합부는 $\mathrm{Cu}$ 패드/리드 이외 $\mathrm{Ag}_{3} \mathrm{Sn}$ 이 추가적인 핵생성 위치가 되므로 동일한 환경에서 HAST를 진행

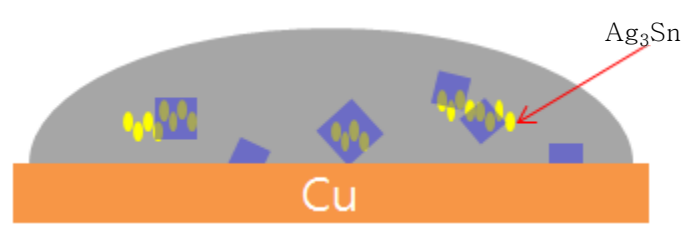

(a)

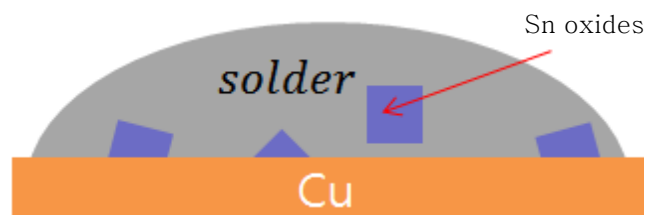

(b)

Fig. 10 Mechanism of Sn-oxide growth : (a) solder with $\mathrm{Ag}(\mathrm{SAC} 305)$ and (b) solder without $\mathrm{Ag}(\mathrm{Sn}-0.7 \mathrm{Cu})$
하였을 때 Figs. 7-9의 결과와 같이 핵생성 경로가 많 아 균일한 크기의 산화물이 많이 생성되었다. 그러나 $\mathrm{Sn}-0.7 \mathrm{Cu}$ 솔더는 비교적 핵생성 위치가 적어 특정 크 기의 산화물이 계속 성장하여 조대한 산화물이 발견된 것으로 판단된다.

\section{$3.3 \mathrm{Ag}$ 함량에 따른 굽힘 특성}

Fig. 11은 SAC305시편의 HAST $72 \mathrm{~h}$ 이후 굽힘 시 험 시 측정한 저항 곡선이다. 굽힘 시험 후 $400 \mathrm{~s}$ 가 지 나면서 저항값은 미세하게 증가하였고, 600 s가 지나면 서 저항이 급격히 증가하면서 파단이 발생한 것으로 판 단된다. 따라서 파단 시점으로 저항이 급격히 증가하여 무한대가 되는 시간으로 정하였다. Fig. 12는 연성회 로기판에 실장된 $\mathrm{SOIC}$ 칩 접합부의 3점 굽힘 시험 결 과이다. SAC305와 $\mathrm{Sn}-0.7 \mathrm{Cu}$ 솔더 모두 HAST 시간 에 상관없이 굽힘 특성이 오차범위 내에서 변함이 없었 다. 즉, $\mathrm{Ag}$ 함량의 유무와 $\mathrm{HAST}$ 시간과는 상관없이

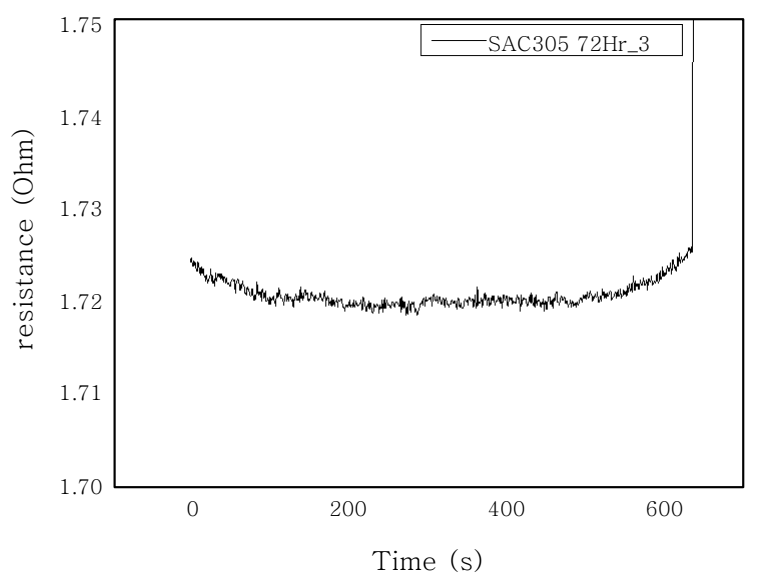

Fig. 11 Resistance behavior of SAC305 solder joints conducted with HAST $72 \mathrm{~h}$

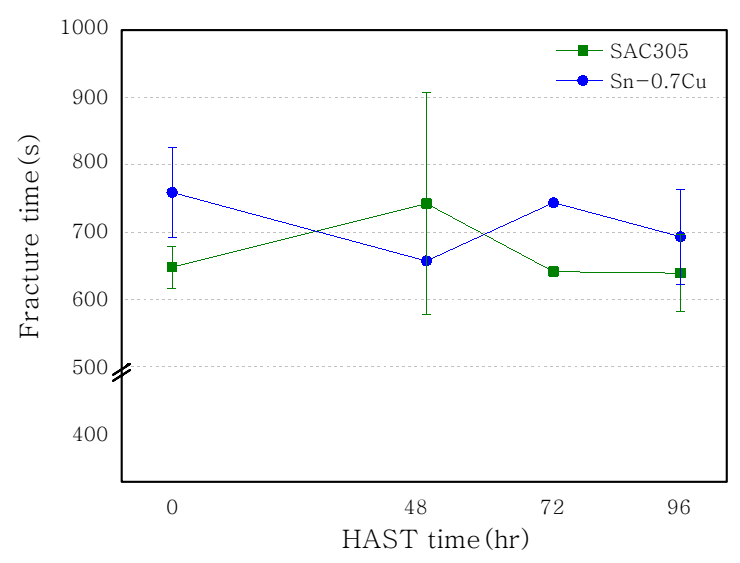

Fig. 12 Fracture time of 3-point bending with respect to HAST time 

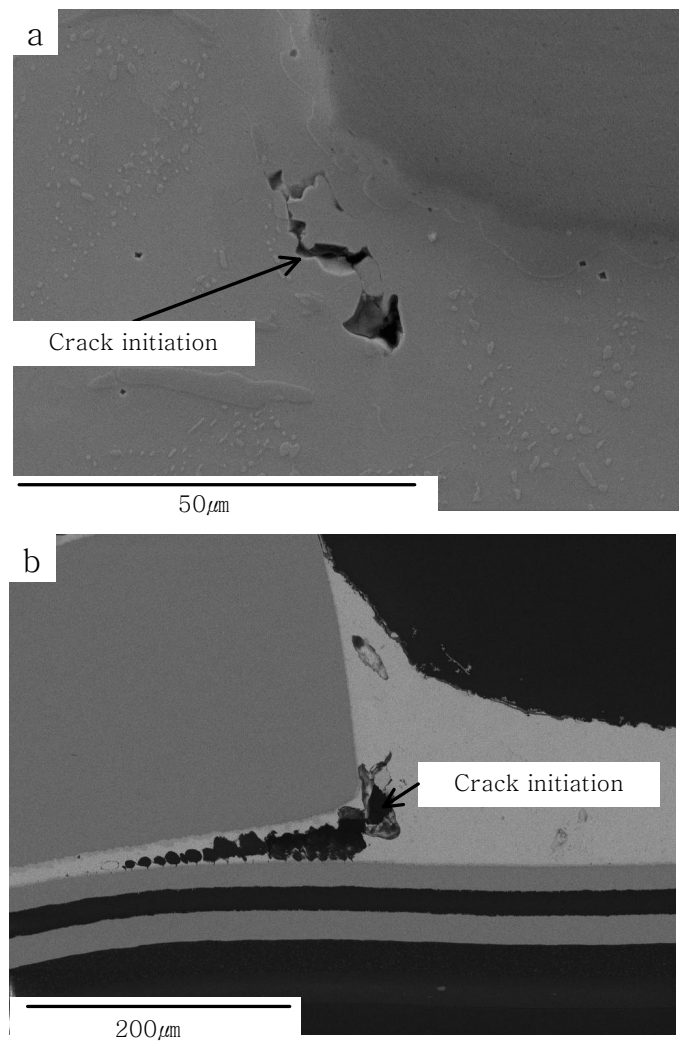

Fig. 13 Crack initiation site of (a) SAC305 tested for $48 \mathrm{~h}$ and (b) Sn- $0.7 \mathrm{Cu}$ tested for $48 \mathrm{~h}$

솔더 접합부에서의 굽힘 특성은 큰 차이가 없었다.

Fig. 13은 $\mathrm{SAC} 305$ 와 $\mathrm{Sn}-0.7 \mathrm{Cu}$ 솔더 접합부의 굽 힘 시험 후 단면을 나타내었다. HAST 시험의 전후 및 시 간에 상관없이 초기 균열은 Fig. 13a에 표시한 칩 부 품과 솔더의 리드프레임 코너 부위에서 시작되었다. 이 렇게 시작된 초기 균열은 Fig. $13 \mathrm{~b}$ 와 같이 부품과 기 판 사이의 경계면을 따라 전파되었다.

Fig. 14는 균열의 전파경로를 나타낸다. SAC305 솔 더 접합부는 $\mathrm{Sn}-0.7 \mathrm{Cu}$ 솔더 접합부와 마찬가지로 $\mathrm{Cu}_{6} \mathrm{Sn}_{5}$ 와 솔더의 경계에서 균열이 전파됐지만, 전파 경로에 내 부 산화물이 있는 경우 내부 산화물을 따라 균열이 전 파된다. $\mathrm{Ag}_{3} \mathrm{Sn}$ 의 산화가 일어나지 않는 $\mathrm{Sn}-0.7 \mathrm{Cu}$ 솔 더 접합부는 균열의 전파경로가 $\mathrm{Cu}_{6} \mathrm{Sn}_{5}$ 와 솔더의 경계 를 따르고 있음을 확인 하였다. 균열이 지나간 경로에 는 연성회로기판의 특성상 굽힘 시험 과정에서 기판이 휘 어지기 때문에 scallop형태로 자라는 $\mathrm{Cu}_{6} \mathrm{Sn}_{5}$ 경계에 횡 균열이 나타났다. 그러나 굽힘 크랙이 시작하는 $\mathrm{Cu}$ 패드 /리본과 솔더의 리드프레임 코너 부위가 $\mathrm{Sn}$ 계 산화물의 위치와 관련이 없기 때문에, 솔더 조성과 HAST 시간에 상관없이 거의 일정한 굽힘강도 결과를 나타낸 것으로 판단된다.
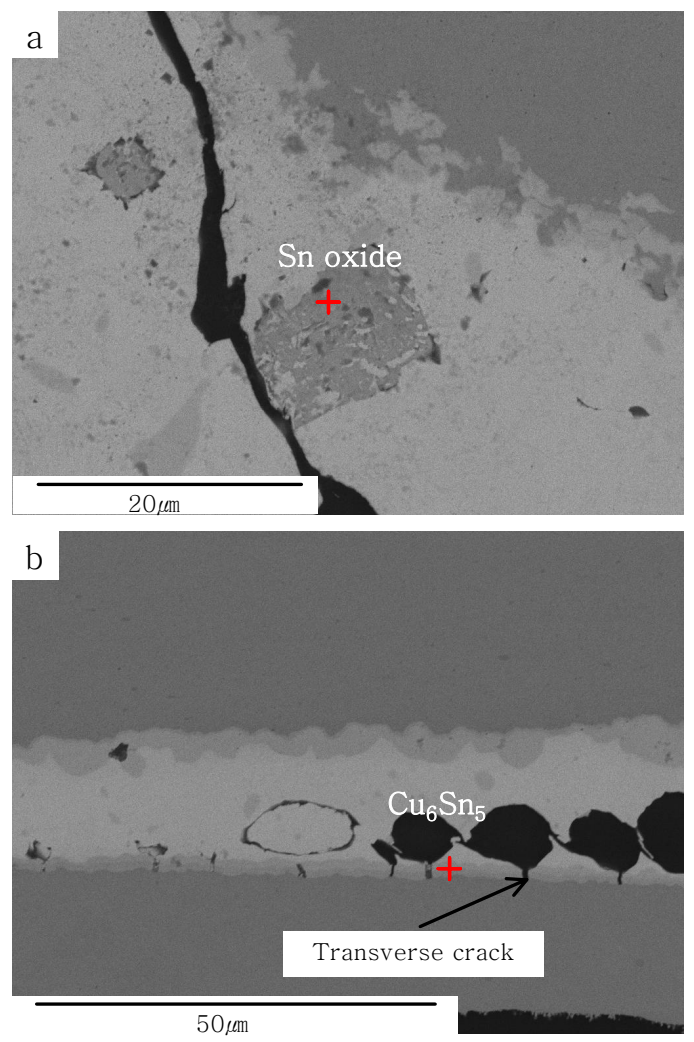

Fig. 14 Crack propagation for (a) SAC305 and (b) Sn$0.7 \mathrm{Cu}$ solder joints

\section{4. 결 론}

본 연구는 고온고습의 가혹한 환경에 노출되어있는 자 동차 전장부품의 신뢰성을 보증하기 위해, 차체부품 접합 에 적용된 연성회로 기판과 $\mathrm{SAC} 305$ 와 $\mathrm{Sn}-0.7 \mathrm{Cu}$ 무 연솔더 접합부의 HAST 굽힘 특성 및 부식거동에 대한 다음과 같은 결과를 도출하였다.

1) $\mathrm{HAST}$ 시험 전 솔더 접합부 표면에만 존재하던 $\mathrm{Sn}$ 계 산화물은 $121^{\circ} \mathrm{C}, 2 \mathrm{~atm}, 100 \% \mathrm{RH}$ 조건의 $\mathrm{HAST}$ 시 험 이후 솔더 내부에서도 발견되었다. HAST 시험 후 $\mathrm{SAC} 305$ 와 $\mathrm{Sn}-0.7 \mathrm{Cu}$ 솔더 접합부는 $\mathrm{Cu}$ 패드/리드와 인접한 부분에 산화물이 분포하였다. 이는 고온고습환 경에서 솔더와 PI 주위에 형성된 수분막의 산화반응 때 문으로, $\mathrm{Ag}$ 가 함유된 $\mathrm{SAC} 305$ 솔더 접합부는 이외에 도 $\mathrm{Ag}_{3} \mathrm{Sn}$ 과 $\mathrm{Sn}$ 의 기전력 차이로 인해 $\mathrm{Ag}_{3} \mathrm{Sn}$ 이 음극 으로 작용해 $\mathrm{Sn}$ 산화물이 핵생성 되었다.

2) $\mathrm{HAST}$ 시험 전 $\mathrm{SAC} 305$ 와 $\mathrm{Sn}-0.7 \mathrm{Cu}$ 솔더의 내 부 산화물 분율은 모두 $1 \mathrm{vol} \%$ 미만이었다. 내부 산화 물 분율은 $48 \mathrm{~h}$ HAST 시험 후 $\mathrm{SAC} 305$ 와 $\mathrm{Sn}-0.7 \mathrm{Cu}$ 솔더 접합부에서 각각 $2.4 \mathrm{vol} . \%$ 와 $2.1 \mathrm{vol} \%$ 로 증가 하였고, $72 \mathrm{~h}$ 에서는 각각 $3.5 \mathrm{vol} \%$ 와 $2.9 \mathrm{vol} \%$ 로 증가하였지만 편차를 고려하면 $48 \mathrm{~h}$ 와 비슷한 값을 보 
였다. HAST 후 내부 산화물의 분율은 증가하였지만, $\mathrm{Ag}$ 유무에 따른 산화물 분율의 차이는 거의 없었다.

3) HAST 시험 전 SAC305 솔더의 산화물 지름은 7.1 $\mu \mathrm{m}$ 이다. $48 \mathrm{~h}$ 와 $72 \mathrm{~h} \mathrm{HAST}$ 시험을 마치면 각각 $9.6 \mu \mathrm{m}$ 와 $9.5 \mathrm{\mu m}$ 로 증가하였지만 $48 \mathrm{~h}$ 과 $72 \mathrm{~h}$ 에서는 크기의 차이 가 거의 없었다. 그리고 $\mathrm{HAST}$ 시험 전 $\mathrm{Sn}-0.7 \mathrm{Cu}$ 솔 더 접합부의 내부 산화물 지름은 $9.3 \mu \mathrm{m}$ 이었고, $48 \mathrm{~h}$ 와 $72 \mathrm{~h} \mathrm{HAST}$ 시험에서는 각각 $11.4 \mu \mathrm{m}$ 와 $14.3 \mu \mathrm{m}$ 로 증가 하였다. $\mathrm{Ag}$ 가 없는 $\mathrm{Sn}-0.7 \mathrm{Cu}$ 솔더 접합부의 내부 산 화물 크기는 $\mathrm{Ag}$ 가 함유된 SAC305 보다 큰 값을 가지 고 있었다.

4) $\mathrm{Ag}$ 함량에 따른 솔더 접합부의 굽힘 특성 변화는 크 랙의 시작 위치가 모두 부품과 솔더의 리드프레임 코너 부위에서 시작하였다. 크랙의 시작은 내부 산화물의 주 요 위치와 일치하지 않았기 때문에, HAST 시간과 솔 더의 종류에 따른 굽힘 특성 변화는 없었다.

\section{감사의 글}

이 과제는 부산대학교 교수국외장기파견지원비에 의 하여 연구되었음.

\section{References}

1. C.F. Han, Q. Liu, D.G. Ivey, Electrochemical composite deposition of Sn-Ag-Cu alloys, Mater. Sci. Eng. B. 164 (2009), 172-1792

2. Commission Directive 2011/37/EU amending Annex II to Directive 2000/53/EC on end-of-life vehicles(ELV Directive), (2011), http://eur-lex.europa.eu/legal-content/ EN/TXT/HTML/?uri=CELEX:32011L0037\&qid=1498 $733250358 \&$ from $=$ en, $(2011)$

3. DIRECTIVE 2000/53/EC OF THE EUROPEAN =PARLIAMENT AND OF THE COUNCIL of 18 September 2000, on end-of life vehicles, http://eur-lex.europa.eu/legalcontent/EN/TXT/PDF/?uri=CELEX:02000L0053-2013 0611\&qid=1405610569066\&from=EN , (2000)

4. C. Meola, Pb-free lectronics Research Manhattan Project Phase I, ACI Technology Inc, (2009)

5. H. Chang, H. Chen, M. Li, L. Wang, Y. Fu. J, Generation of Tin(II) Oxide Crystals on Lead-Free Solder Joints in Deionized Water Electron, Mater, 38 (2009), 2170-2178
6. E. Angelini, G. Zanicchi, R. Carlini, R. Marazza, Electrochemical corrosion study of $\mathrm{Sn}-3 \mathrm{Ag}-3 \mathrm{Cu}$ solder alloy in $\mathrm{NaCl}$ solution F.Rosalbino, Electrochimica Acta, 54 (2009), 7231-7235

7. D. Li, P. P. Conway, C. Liu, Corrosion characterization of tin-lead and lead free solders in 3.5 wt. $\% \mathrm{NaCl}$ solution, Corrosion Science, 50 (2008), 995-1004

8. K. Yokoyama, D. Tsuji, J. Sakai, Fracture of sustained tensile-loaded $\mathrm{Sn}-3.0 \mathrm{Ag}-0.5 \mathrm{Cu}$ solder alloy in $\mathrm{NaCl}$ solution, Corrosion Science, 53 (2011), 3331-3336

9. M. Wang, J. Wang, H. Feng, W. Ke, In-situ observation of fracture behavior of $\mathrm{Sn}-3.0 \mathrm{Ag}-0.5 \mathrm{Cu}$ lead-free solder during three-point bending tests in ESEM, Materials Science \& Engineering A, 558 (2012), 649-655

10. F. Rosalbino, E. Angelini, G. Zanicchi, R. Marazza, Corrosion behaviour assessment of lead-free Sn-Ag-M (M $=\mathrm{In}, \mathrm{Bi}, \mathrm{Cu}$ ) solder alloys, Materials Chemistry and Physics, 109 (2008), 386-391

11. J. Bang, D. Yu, Y. Ko, J. Yoon, C. Lee, Lead-free Solder for Automotive Electronics and Reliability Evaluation of Solder Joint, J. of Welding and Joining, 34(1), (2016), 26-34 (in Korean)

12. Y. Ko, S. Yoo, C. Lee, Evaluation on Reliability of High Temperature Lead-free Solder for Automotive Electronics, Journal of Microelectronics \& Packaging Society, 17 (4), (2010), 35-40

13. W. S. Hong, C. M. Oh, Degradation Behavior of Solder Joint and Implementation Technology for Lead-free Automotive Electronics, Journal of KWJS, 31(3), (2013), 22-30 (in Korean)

14. H. Kang, M. Lee, D. Sun, S. Pae, J. Park, Formation of octahedral corrosion products in Sn-Ag flip chip solder bump, Scripta Materialia, 108 (2015), 126-129

15. S. Lahokallio, K. Saarinen, L. Frisk, Effect of HighHumidity Testing on Material Parameters of Flexible Printed Circuit Board Materials, Journal of ELECTRONICS MATERIALS, 42(9), (2013)

16. M. Wang, J. Wang, H. Feng, W. Ke, Effects of microstructure and temperature on corrosion behavior of $\mathrm{Sn}$ 3.0Ag-0.5Cu lead-free solder of $\mathrm{Sn}-3.0 \mathrm{Ag}-0.5 \mathrm{Cu}$ lead-free solder, J Mater Sci, Mater Electron, (2012), 23:148155

17. M. Wang, J. Wang, H. Feng, W. Ke, Effect of Ag3Sn intermetallic compounds on corrosion of $\mathrm{Sn}-3.0 \mathrm{Ag}-0.5 \mathrm{Cu}$ solder under high-temperature and high-humidity condition, Corrosion Science, 63 (2012), 20-28 